Review

\title{
Regulation of Inflammation by Short Chain Fatty Acids
}

\author{
Marco A.R. Vinolo *, Hosana G. Rodrigues, Renato T. Nachbar and Rui Curi \\ Department of Physiology and Biophysics, Institute of Biomedical Sciences-ICB-I, \\ Sao Paulo University, Brazil; E-Mails: hosanagr@icb.usp.br (H.G.R.); \\ nachbar@icb.usp.br (R.T.N.); ruicuri@icb.usp.br (R.C.) \\ * Author to whom correspondence should be addressed; E-Mail: mramirez@icb.usp.br; \\ Tel.: +55-11-3091-7245; Fax: +55-11-3091-7285.
}

Received: 18 July 2011; in revised form: 21 September 2011 / Accepted: 8 October 2011 / Published: 14 October 2011

\begin{abstract}
The short chain fatty acids (SCFAs) acetate $\left(\mathrm{C}_{2}\right)$, propionate $\left(\mathrm{C}_{3}\right)$ and butyrate $\left(\mathrm{C}_{4}\right)$ are the main metabolic products of anaerobic bacteria fermentation in the intestine. In addition to their important role as fuel for intestinal epithelial cells, SCFAs modulate different processes in the gastrointestinal (GI) tract such as electrolyte and water absorption. These fatty acids have been recognized as potential mediators involved in the effects of gut microbiota on intestinal immune function. SCFAs act on leukocytes and endothelial cells through at least two mechanisms: activation of GPCRs (GPR41 and GPR43) and inhibiton of histone deacetylase (HDAC). SCFAs regulate several leukocyte functions including production of cytokines (TNF- $\alpha$, IL-2, IL-6 and IL-10), eicosanoids and chemokines (e.g., MCP-1 and CINC-2). The ability of leukocytes to migrate to the foci of inflammation and to destroy microbial pathogens also seems to be affected by the SCFAs. In this review, the latest research that describes how SCFAs regulate the inflammatory process is presented. The effects of these fatty acids on isolated cells (leukocytes, endothelial and intestinal epithelial cells) and, particularly, on the recruitment and activation of leukocytes are discussed. Therapeutic application of these fatty acids for the treatment of inflammatory pathologies is also highlighted.
\end{abstract}

Keywords: short chain fatty acids; inflammation; leukocytes; neutrophils; butyrate; propionate; acetate

Abbreviations: ALI: acute lung injury; AT: adipose tissue; CINC-2: cytokine induce neutrophil chemoattractant-2; FAK: focal adhesion kinase; fMLP: 
$N$-formyl-Methionine-Leucine-Phenylalanine; GI: gastrointestinal; GPCR: G protein coupled receptors; GRO: growth-related oncogene; HAT: histone acetyltransferase; HDAC: histone deacetylase; HUVEC: human umbilical vein endothelial cells; IBD: inflammatory bowel disease; ICAM-1: inter-cellular adhesion molecule-1; IEC: Intestinal epithelial cells; IgA: immunoglobulin A; IL: interleukin; IFN: Interferon; IP-10: Interferon (IFN)-gamma-inducible protein-10; LFA-1: lymphocyte function-associated antigen-1; MAC-1: Macrophage-1 antigen; MAPK: mitogen activated protein kinase; MCP-1: macrophage chemoattractant protein; NF-кB: nuclear factor-kappa B; NO: Nitric oxide; PI3K: phosphoinositide-3 kinase; PLA 2 : phospholipase $\mathrm{A}_{2}$; PLC: phospholipase $\mathrm{C}$; $\mathrm{PGE}_{2}$ : prostaglandin $\mathrm{E}_{2}$; PKB: protein kinase $\mathrm{B}$; PMA: phorbol-12 myristate-13 acetate; PPAR- $\gamma$ : peroxisome proliferator-activated receptor gamma; ROS: reactive oxygen species; SCFAs: short chain fatty acids; SM: skeletal muscle; TNF- $\alpha$ : tumor necrosis factor- $\alpha$; T reg: regulatory T cells; VCAM-1: vascular cell adhesion molecule-1.

\section{Introduction}

Human mucosal sites are colonized by an astonishing number of microorganisms (it is estimated that $90 \%$ of the cells in our body are microbes) of different kingdoms (e.g., fungi and bacteria) and genera (e.g., Bifidobacterium, Eubacterium, Fusobacterium, Escherichia and Candida), which are collectively referred to as microbiota or microflora. Most of these non-human cells are located in the gastrointestinal (GI) tract where they exert protective (i.e., natural defense barrier and production of anti-microbial factors), structural (i.e., development of immune system and induction of IgA) and metabolic (i.e., fermentation of non-digestible dietary residues, synthesis of vitamins and ion absorption) functions [1].

A considerable advance in the understanding of the role of gut microbiota in both physiological and pathological conditions has been obtained. Important effects of these microorganisms and their products have been demonstrated not only in the GI tract but also in adipose tissue, immune and nervous systems [2-4]. Modifications in the proportions of microorganisms in the gut (qualitatively or quantitatively) and, consequently, in the concentrations of the compounds produced and released by them in the lumen have been suggested to play a role in the development of pathological conditions including inflammatory bowel disease (IBD), colon cancer, obesity and type 1 and 2 diabetes mellitus [3-6] (Figure 1).

Some of the compounds that have been implicated in the effects of microbiota on host cells are microbial-derived ligands of toll like receptors (TLRs) such as LPS and flagellin, which activate, respectively, TLR-4 and -5 and modulate distinct aspects of host metabolism and immune responses [3,7]. Other compounds derived from the microbiota such as ATP also modulate the function of host tissues. This nucleotide induces the differentiation of an important subset of CD4+ lymphocytes, the Th17 cells [8]. Short chain fatty acids (SCFAs), which are the major metabolic products of anaerobic bacteria fermentation, have been suggested to be the link between microbiota and host tissues. The concentration of these fatty acids in the GI tract and blood may predispose to or prevents pathological 
conditions such as IBD, cancer and diabetes. Modifications in the concentrations or the ability of host tissues to use SCFAs have been described in these conditions [9-13].

Figure 1. Schematic representation of the interaction between gut microbiota and host tissues. Soluble factors (e.g., LPS, flagellin, ATP and short chain fatty acids (SCFAs)) released by gut microbiota modulate host tissues such as pancreas, skeletal muscle (SM), adipose tissue (AT), leukocytes, liver and blood vessels function and may play a role in the development of several diseases including cancer, inflammation and diabetes.

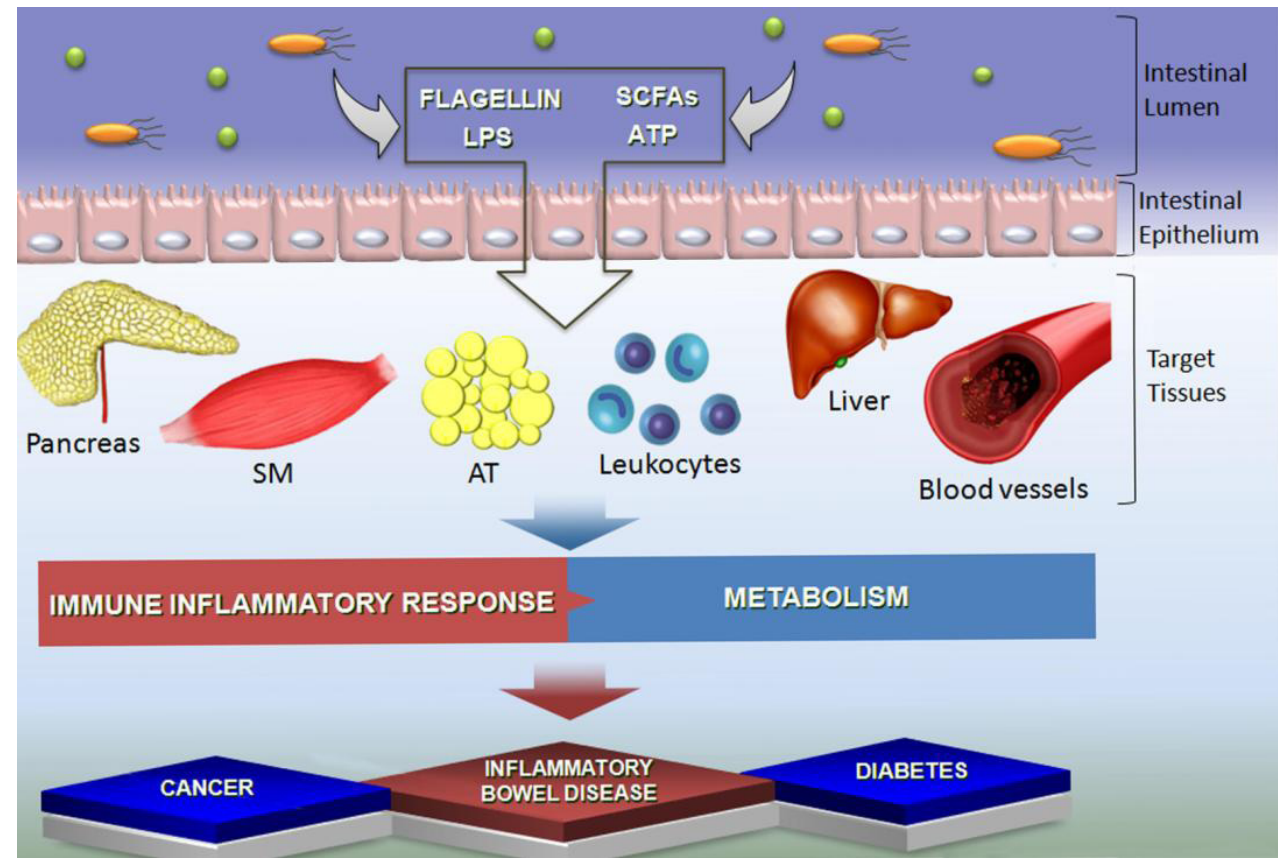

Acetate $\left(\mathrm{C}_{2}\right)$, propionate $\left(\mathrm{C}_{3}\right)$ and butyrate $\left(\mathrm{C}_{4}\right)$ are found in the human intestine at concentrations of approximately $13 \mathrm{mM}$ in the terminal ileum, $\sim 130 \mathrm{mM}$ in the caecum and $\sim 80 \mathrm{mM}$ in the descending colon [14]. They are produced by anaerobic fermentation of non-digestible dietary residues and endogenous epithelial-derived mucus in the gut. SCFAs released in the intestinal lumen are readily absorbed and used as energy source by colonocytes ( 5 to $10 \%$ of human basal energy requirements are provided by SCFAs) and also by other tissues including liver and muscle [15]. SCFAs, of which butyrate is the most studied, modulate different processes including cell proliferation and differentiation, hormones secretion (e.g., leptin and peptide YY) [16,17] and activation of immune/inflammatory responses $[4,18]$. Therefore, in addition to energy supply, these fatty acids have other important functions.

\section{Effects of SCFA on Leukocyte Recruitment}

Leukocytes are recruited and migrate from the bloodstream to the inflamed tissue in a multistep process that involves expression and activation of several proteins including adhesion molecules and chemokines and their coordinated interaction with endothelial cells [19]. Cell adhesion molecules such as selectins (E-, P- and L-selectins), integrins (e.g., lymphocyte function-associated antigen-1 (LFA-1) and macrophage antigen-1 (Mac-1)) and their counter ligands molecules (specific carbohydrates, vascular cell adhesion molecule-1 (VCAM-1), intercellular adhesion molecule-1 (ICAM-1) and others) play a central role in rolling, adhesion and transendothelial migration of leukocytes. Once in the 
extravascular space, leukocytes sense distinct sets of chemoattractants and move in the direction of the inflammatory foci [19].

SCFAs modify the recruitment of circulating leukocytes to the inflammatory site $[4,20]$. Interestingly, the effect of SCFAs on leukocytes varies depending on the experimental condition. Application of SCFAs in a sterile air pouch in the rat trunk induces a significant recruitment of leukocytes, particularly neutrophils [20]. However, oral administration of tributyrin, a pro-drug of butyrate, reduces migration of leukocytes to the peritoneum in response to inflammatory stimuli (oyster glycogen solution) [21]. This apparent discrepancy in the effects of SCFAs on leukocyte recruitment can be explained, at least in part, by their ability to act on different cells involved in the inflammation including neutrophils and macrophages, in which they act, respectively, inducing cell migration [20,22] and suppressing the production of pro-inflammatory cytokines [23]. This issue will be further discussed in the next sections of this review.

\subsection{Leukocyte Chemotaxis}

SCFAs induce directional migration (chemotaxis) of neutrophils in vitro, an effect that is dependent on the activation of a $\mathrm{G}$ protein-coupled receptor, the GPR43 [4,22,24,25]. This receptor was shown, as in the case of GPR41 and GPR109A, to be activated by SCFAs [26-28]. GPR43 couples to Gi/o and $\mathrm{Gq}$ proteins and is expressed in leukocytes, particularly neutrophils and monocytes, and in adipocytes [16,22,26,27]. Binding of agonists (SCFAs or synthetic agonists such as phenylacetamide-1 and -2$)$ to this receptor activates several intracellular pathways including mitogen-activated protein kinases (MAPKs), protein kinase $\mathrm{C}$ and transcriptional factors such as activating transcriptional factor-2, also known as ATF-2 [4] (Figure 2(A)).

Evidence was obtained that SCFAs or phenylacetamide-1 elicit GPR43-dependent activation of PKB and MAPKs (p38 and ERK) in neutrophils. These responses were sensitive to pertussis toxin treatment, indicating a role for Gi proteins [25]. GPR43 agonists also induce rapid and transient activation of Rac1/2 GTPases and phosphorylation of ribosomal protein S6 in neutrophils. Genetic and pharmacological interventions that inhibit PI3K $\gamma$, Rac2, p38 and ERK dramatically reduce the GPR43-dependent chemotaxis. These results are indicative of the participation of these signaling pathways in the movement of neutrophils in response to SCFAs [25].

Despite the fact that SCFAs clearly act as chemoattractant agents for neutrophils in vitro, the relevance of this interaction (SCFAs/GPR43) for the recruitment of leukocytes in the presence of other chemoattractants and molecules that regulate the activation of these cells is not clear. Evidence for an interaction between SCFAs/GPR43 and other chemottractant receptors has been provided [20,22,24]. Chemotaxis of neutrophils induced by formyl-Met-Leu-Phe (fMLP) or KC (CXCL1), an important chemokine for mouse neutrophils, has been shown to be either increased [24] or not affected by SCFAs [20,22]. SCFAs also reduce the surface expression of chemoattractant receptors (e.g., C5aR and CXCR2). This latter result is suggestive of an inhibitory effect of these fatty acids on neutrophil migration in response to other chemoattractants [4]. 
Figure 2. Schematic overview of the signaling pathways activated downstream of GPR43 receptors and representation of the effects of SCFAs through inhibition of histone deacetylase (HDAC) activity (B). GPR43 couples to Gi and Gq proteins, which interact with several proteins including adenylate cyclase, small G proteins (e.g., Rac and Rho), mitogen-activated protein kinases (MAPK), phospholipase $\mathrm{C}$ (PLC) and $\mathrm{A}_{2}\left(\mathrm{PLA}_{2}\right)$, ion channels and transcription factors (A). SCFAs may also act on cells through inhibition of HDAC (B). This class of enzymes, together with histone acetyltransferase (HAT), controls the acetylation state of histones and non-histone proteins and, consequently, modulates the transcription of several genes.

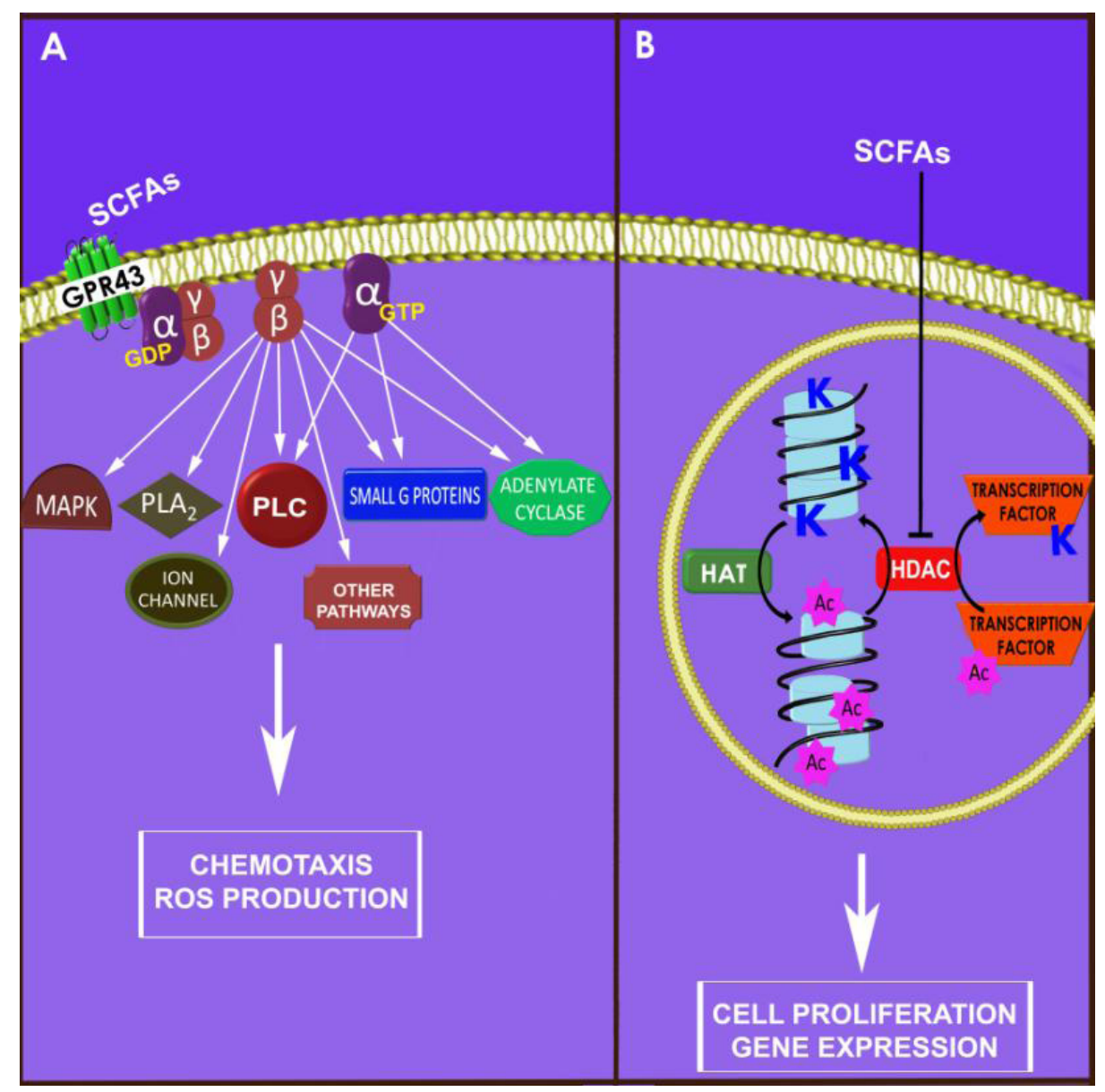

In contrast to what has been found in neutrophils, no effect of butyrate was observed in non- stimulated macrophage [29]. These authors have also found inhibition of LPS-induced migration of macrophages by butyrate [29]. This latter effect seems to be the result of inhibition of HDAC activity and, consequently, suppression of LPS-activation of Src [29], an enzyme that phosphorylates focal adhesion kinase (FAK), which has an important role in macrophage locomotion [30].

\subsection{Chemokine Production}

In addition to their chemotatic effect on neutrophils, SCFAs also modulate production and release of chemokines and expression of adhesion molecules in neutrophils [20] and endothelial cells [31-33], which may be relevant to the effect of these fatty acids on leukocyte recruitment. 
Chemokines attract and activate leukocytes. SCFAs modulate the production of these inflammatory mediators by neutrophils and other cells. Our group has shown that propionate and butyrate reduce the LPS-stimulated production of CINC-2 (also known as CXCL-2 and -3) by neutrophils [21] and by macrophages (data not published). This effect can explain, at least in part, the reduction of leukocyte recruitment observed in response to inflammatory stimuli after oral administration of tributyrin [21].

Cox et al. described the inhibitive effect that SCFAs, of which butyrate was the most and acetate the less potent, have on the production of macrophage chemoattractant protein-1 (MCP-1, also known as CCL2) either in the presence or absence of LPS [34]. This chemokine attracts monocytes/ macrophages and lymphocytes. We have found that oral administration of butyrate reduces the production of MCP-1 by adipose tissue in diet-induced obese mice (data not published). MCP-1 plays an important role in macrophage recruitment and accumulation in the adipose tissue; an important factor for establishing insulin resistance in obese patients.

IEC are source of cytokines and chemokines that regulate physiological and pathological processes in the GI tract. Because IEC are in contact with high concentrations of SCFAs, the effects of these fatty acids on these cells have been intensely investigated. Butyrate modulates the expression and release of IL-8, MCP-1 and growth-related oncogene (GRO, also known as CXCL-1) by IEC in response to cytokines and microbial-derived molecules such as peptideoglycan [35-38]. In human colonic subepithelial myofibroblasts, butyrate, but not acetate and propionate, blocks the expression of interferon (IFN)-gamma-inducible protein-10 (IP-10, CXCL-10), a chemoattractant for T lymphocytes and monocytes [39]. These effects that SCFAs have on chemokines may be relevant for the GI tract inflammatory and immune response. By changing the type or the amount of chemokines produced by intestinal cells, SCFAs may alter the recruitment of leukocytes and the pattern of inflammatory mediators produced in this tissue.

\subsection{Expression of Adhesion Molecules}

SCFAs reduce the in vitro adherence of monocytes and lymphocytes to human umbilical vein endothelial cells (HUVEC) $[31,32,40]$. This effect is associated with an attenuation of NFKB and PPAR $\gamma$ activities and, consequently, suppression of adhesion molecules expression (ICAM-1 and VCAM-1) in endothelial cells. In monocytes, butyrate also reduces the constitutive and IFN- $\gamma$-induced expression of LFA-3 and ICAM-1 [41].

Butyrate or cholesteryl butyrate solid lipid nanoparticles have anti-adhesive effects on neutrophil interaction with HUVEC in the presence of fMLP or IL-1 $\beta$ [42]. Sina et al. found a significant reduction in L-selectin surface levels after incubation of neutrophils with propionate and butyrate [24]. We have found that acetate, propionate and butyrate do not affect the expression of $\beta 2$ integrins in neutrophils, but increase that of L-selectin after $4 \mathrm{~h}$ of incubation [20]. However, the effects on L-selectin may not be relevant in vivo, since modifications in the expression of this adhesion molecule do not affect neutrophil rolling and adhesion [43]. Considering these findings, we hypothesize that SCFAs may affect neutrophil interaction with endothelial cells due to their effect on endothelial cells rather than on neutrophils. 


\section{Modulation of Leukocyte Effector Mechanisms by SCFAs}

\subsection{Production of Inflammatory Mediators by Immune Cells}

Macrophages are the major source of inflammatory mediators involved in insulin resistance, atherosclerosis, rheumatoid arthritis and neurodegenerative diseases [44-47]. Once activated, macrophages produce large amounts of TNF- $\alpha$, IL- $1 \beta$ and IL-6, chemokines, nitric oxide (NO) and arachidonic acid derivatives such as tromboxane $A_{2}$, prostaglandins $E_{2}$ and $F_{1 \alpha}$.

SCFAs modulate the production of inflammatory mediators by macrophages as shown in Table 1 . SCFAs, mainly butyrate, suppress the LPS- and cytokine-stimulated production of pro-inflammatory mediators including TNF- $\alpha$, IL- 6 and NO. Butyrate also enhances the release of the anti-inflammatory cytokine IL-10. However, this latter effect was not found in all studies; for example, Cox et al., instead of an increase, found an attenuation of IL-10 production by monocytes treated with SCFAs [34].

Table 1. Effect of SCFAs in the production of inflammatory mediators by isolated cells.

\begin{tabular}{|c|c|c|c|}
\hline Cell type & Effect observed & Effective fatty acid & Reference \\
\hline Raw 264.7 cells & $\begin{array}{c}\downarrow \text { TNF- } \alpha, \text { IL- } 6, \text { NO, } \\
\uparrow \text { IL-10 }\end{array}$ & $\mathrm{Bt}$ & {$[23,48]$} \\
\hline Mononuclear cells of the blood & $\downarrow \mathrm{TNF}-\alpha, \uparrow \mathrm{PGE}_{2}$ & $\mathrm{Bt}$ & [49] \\
\hline Monocytes and macrophages & $\downarrow$ TNF- $\alpha$ & $\mathrm{Bt}$ & [50] \\
\hline \multirow[t]{2}{*}{ Monocytes } & $\begin{array}{c}\downarrow \text { TNF- } \alpha, \text { IL-12, IFN- } \gamma \\
\uparrow \text { IL-10 }\end{array}$ & $\mathrm{Bt}$ & {$[51]$} \\
\hline & $\downarrow \mathrm{MCP}-1, \mathrm{IL}-10, \uparrow \mathrm{PGE}_{2}$ & $\mathrm{Ac}, \mathrm{Pr}$ and $\mathrm{Bt}$ & [34] \\
\hline $\begin{array}{l}\text { Microglial cells } \\
\text {-N9 cells }\end{array}$ & $\uparrow$ IL-6, NO & Pr and $\mathrm{Bt}$ & {$[52]$} \\
\hline -Rat primary microglia & $\downarrow$ TNF- $\alpha$, IL-6, NO & $\mathrm{Bt}$ & {$[52]$} \\
\hline -Murine BV2 cell & $\downarrow \mathrm{NO}$ & $\mathrm{Bt}$ & {$[53]$} \\
\hline $\begin{array}{c}\text { Mesencephalic } \\
\text { neuron-glia cultures }\end{array}$ & $\downarrow$ TNF- $\alpha$, NO & $\mathrm{Bt}$ & {$[54]$} \\
\hline Kupffer cells & $\downarrow$ TNF- $\alpha, \uparrow \mathrm{PGE}_{2}$ & $\mathrm{Bt}$ & [55] \\
\hline
\end{tabular}

Abbreviations: acetate (Ac), propionate (Pr), butyrate (Bt), interferon- $\gamma$ (IFN- $\gamma$ ), interleukin-6 (IL-6), interleukin-10 (IL-10), interleukin-12 (IL-12), macrophage chemoattractant protein (MCP), nitric oxide (NO), prostaglandin $\mathrm{E}_{2}\left(\mathrm{PGE}_{2}\right)$, tumor necrosis factor- $\alpha(\mathrm{TNF}-\alpha)$. ( $\uparrow$ ) increase and $(\downarrow)$ reduction.

The main mechanism described for these effects is the attenuation of HDAC activity. Among the SCFAs, butyrate is the most potent, whereas acetate is the least potent inhibitor of HDAC $[18,56]$. This enzyme, together with the histone acetyltransferases (HAT), controls the degree of protein acetylation. By inhibiting the HDAC activity, SCFAs increase the acetylation of histone and non histone proteins including $\mathrm{NF \kappa B}$, MyoD, p53 and N-FAT [57] and, consequently, modulate gene expression (Figure 2(B)). 
The production of prostaglandin $\mathrm{E}_{2}\left(\mathrm{PGE}_{2}\right)$ is also modified by SCFAs. These fatty acids stimulated the in vitro production of this eicosanoid by human monocytes [58]. In accordance with this result, induction of $\mathrm{PGE}_{2}$ production was observed three hours after intraplantar injection of SCFAs and LPS in rat paws [34]. $\mathrm{PGE}_{2}$ has been considered an anti-inflammatory prostanoid due to its ability to attenuate the production of IL- $1 \beta$ and TNF- $\alpha$ by macrophages and Th1 differentiation. However, there is now evidence in favor of a pro-inflammatory action of this molecule [59]. $\mathrm{PGE}_{2}$, through activation of its receptor EP4, facilitates Th1 differentiation and Th17 expansion, two subsets of T helper involved in immune inflammation [59,60]. Considering these findings, SCFAs may also affect $\mathrm{T}$ cell differentiation.

In addition to the classical eicosanoids, such as $\mathrm{PGE}_{2}$, other lipid mediators are also generated from polyunsaturated fatty acids including lipoxins, resolvins, protectins and maresins [61]. Despite their relevance to the resolution of the inflammatory process [61], at the moment, no study has been conducted in order to investigate the effect of SCFAs on the production of these lipid mediators.

Anti-inflammatory actions of SCFAs have been also observed in neutrophils. Acetate, propionate and butyrate at $30 \mathrm{mM}$ reduce TNF- $\alpha$ production by LPS-stimulated human neutrophils [62]. Propionate and butyrate inhibit the expression of pro-inflammatory mediators (TNF- $\alpha$, CINC- $2 \alpha \beta$ and NO) in rat neutrophils, an effect that seems to involve attenuation of NF- $\kappa B$ activation [21].

Microglial cells are resident immune cells of the central nervous system (CNS). Activation of these cells leads to production of several inflammatory mediators (e.g., cytokines and NO) that participate in the defense reaction of the CNS against insults including microorganisms and damaged cells [63]. Chronic or excessive activation of these cells has detrimental effects on the CNS and seems to be involved in the initiation and progression of neurodegenerative diseases including Alzheimer and Parkinson's disease. In spite of some controversy about the effect of SCFAs on microglial production of inflammatory mediators [52,53], most of the studies indicate that these fatty acids attenuate microglial activation, an effect that seems to involve HDAC inhibition $[53,54]$. These observations and the data obtained in vivo [64] support the proposition that SCFAs and other inhibitors of HDAC may be useful in preventing inflammation in the CNS. Indeed, Kim et al. [64] have shown that butyrate, valproic acid and trichostatin A (all inhibitors of HDAC activity) present antineuroinflammatory and neuroprotective effects in the ischemic brain of rats.

\subsection{Effectors Mechanisms of Phagocytes}

Once in the inflammatory site, neutrophils and macrophages internalize, kill and digest bacteria and fungi through mechanisms including production of reactive oxygen species (ROS) and release of granule enzymes. SCFAs affect the production of ROS and the phagocytic capacity of phagocytes [4,65-67]. This effect is important in the course of anaerobic bacteria infection. Both inhibition $[65,66,68]$ and stimulation $[4,68]$ of neutrophil phagocytosis by SCFAs have been described. In macrophages, butyrate reduce the phagocytic activity, an effect that probably arises from its inhibitory action on cell differentiation and maturation [69].

The effects of SCFAs on ROS production by neutrophils remain controversial. Some groups have found that SCFAs induce ROS production [4,70,71], whereas others have shown inhibition [65,67,72-74]. The discrepancy in the results obtained may be explained by differences in the protocols used 
such as the concentrations of SCFAs, measurement of ROS by using different methodologies (e.g., lucigenin-amplified chemiluminescence or reduction of cytochrome c), stimuli (e.g., PMA or fMLP), solution $\mathrm{pH}$, source and state of neutrophil activation (e.g., neutrophils isolated from human blood or elicited rat neutrophils).

\subsection{Lymphocyte Activation and Response}

Lymphocytes are involved in the adaptive immune response. These cells display membrane receptors that recognize a broad range of non-self antigens and allow them to generate specific responses to eliminate invading pathogens and infected or tumoral cells. SCFAs modify lymphocytes function as follows:

- T-cell proliferation: butyrate inhibits lymphocyte proliferation in response to several stimuli including concanavalin-A and immobilized anti-CD3 monoclonal antibody $[41,75]$.

- Production of cytokines: incubation of lymphocytes with butyrate reduces the production of interleukin-2; this cytokine stimulates growth, differentiation and survival of antigen-selected T-lymphocytes, and interferon- $\gamma($ IFN- $\gamma$ ) after stimulation with concanavalin-A or anti-CD3 and anti-CD8 [76,77]. This latter cytokine is particularly important in response to viral infection, tumor cells and in auto-immune conditions. On the other hand, butyrate presents an opposite effect on the production of IL-10 by lymphocytes [75].

- Production of regulatory $\mathrm{T}\left(\mathrm{T}_{\text {reg }}\right)$ cells: this subpopulation of $\mathrm{T}$ cells actively suppresses immune function and is considered an attractive target for the treatment of immunological and inflammatory pathologies. HDAC inhibitors enhance the production and suppressive function of regulatory $\mathrm{T}$ cells [77]. Considering that SCFAs, as previously described, also suppress the activity of HDAC, we hypothesize that these fatty acids may also exert their effects on inflammation and immune responses through regulation of this subset of $\mathrm{T}$ cells.

\section{Therapeutical Application of SCFAs in Inflammatory Conditions}

Several studies have attempted to use SCFAs or their derivatives therapeutically in inflammatory conditions in vivo, in both human and animal models. Some of these studies are summarized in Table 2.

A large number of studies in which SCFAs were provided by different forms including ingestion of dietary fiber, use of enemas or oral administration of sodium butyrate were performed to investigate their effects on IBD. Although SCFAs or compounds (dietary fibers) that increase the availability of these fatty acids present beneficial effects in intestinal inflammation, this positive effect is not consensual. This discrepancy may be due to the use of distinct experimental protocols. Further studies are necessary to establish the dose, frequency and form of SCFAs administration in order to optimize results. Other aspects, such as stage of disease and possibility of association with other drugs, must also be investigated in more detail. 
Table 2. Effects of SCFAs or their derivatives in inflammatory conditions.

\begin{tabular}{|c|c|c|c|}
\hline Disease & $\begin{array}{c}\text { Route of administration } \\
\text { and dosage }\end{array}$ & Effect & Reference \\
\hline \multirow{8}{*}{$\begin{array}{l}\text { Inflammatory } \\
\text { bowel disease }\end{array}$} & $\begin{array}{c}\text { Diet with RS } \\
(1.53 \mathrm{~kg} / 10 \mathrm{~kg} \text { of diet })\end{array}$ & $\begin{array}{l}\text { Improvement of symptoms; epithelial cell } \\
\text { proliferation; regeneration of laminin; } \\
\text { growth of intestinal bacteria }\end{array}$ & {$[78]$} \\
\hline & $\begin{array}{l}\text { Diet supplemented with } \\
\text { cellobiose }(9 \%)\end{array}$ & $\begin{array}{l}\text { Reduction of weight loss; diminished } \\
\text { tissue edema; attenuation of inflammatory } \\
\text { cytokine concentrations }\end{array}$ & [79] \\
\hline & $\begin{array}{l}\text { Fiber supplementation } \\
(5 \%) \text { before and after } \\
\text { TNBS colitis }\end{array}$ & $\begin{array}{l}\text { Reduction in MPO and NO synthase } \\
\text { activities; restoration of colonic } \\
\text { glutathione levels; diminished TNF- } \alpha \\
\text { concentrations }\end{array}$ & {$[80]$} \\
\hline & \multirow{2}{*}{$\begin{array}{l}\text { SB enemas } \\
(100 \mathrm{mM})\end{array}$} & $\begin{array}{l}\text { Increased the duration of pain in rats } \\
\text { with colitis }\end{array}$ & {$[81]$} \\
\hline & & $\begin{array}{l}\text { Improves clinical symptoms and } \\
\text { inflammatory scores }\end{array}$ & {$[82]$} \\
\hline & $\begin{array}{l}\text { SB enemas } \\
(100 \mathrm{mM})\end{array}$ & $\begin{array}{l}\text { Minor effects on colonic inflammation } \\
\text { and oxidative stress; increased IL-10/ } \\
\text { IL-12 ratio and CCL5 concentrations }\end{array}$ & {$[83]$} \\
\hline & $\begin{array}{l}\text { 5-ASA }(2 \mathrm{~g})+\mathrm{SB} \\
(80 \mathrm{mM}) \text { enemas }\end{array}$ & $\begin{array}{l}\text { Improvement versus the baseline; only } \\
\text { one remission }\end{array}$ & [84] \\
\hline & $\begin{array}{c}\text { Oral SB } \\
(10 \mathrm{mg} / \mathrm{kg})\end{array}$ & $\begin{array}{l}\text { Improvement of mucosa lesion and } \\
\text { attenuation of the inflammatory profile of } \\
\text { intestinal mucosa and local lymph nodes } \\
\text { in a model of DSS-induced colitis }\end{array}$ & {$[85]$} \\
\hline \multirow{3}{*}{ Sepsis and ALI } & $\begin{array}{l}\mathrm{SB}(500 \mathrm{mg} / \mathrm{kg}) \\
\text { intravenous (i.v.) } \\
\text { injection } \\
\end{array}$ & $\begin{array}{l}\text { Reduced serum alanine aminotransferase, } \\
\text { MPO activity and creatinine } \\
\text { concentrations; improved survival rates }\end{array}$ & {$[86]$} \\
\hline & $\begin{array}{l}\text { Oral butyrate } \\
(10 \mathrm{mg} / \mathrm{kg})\end{array}$ & $\begin{array}{l}\text { Attenuation of lung histopathological } \\
\text { changes, alveolar hemorrhage and } \\
\text { neutrophil infiltration }\end{array}$ & [87] \\
\hline & $\begin{array}{l}\text { TSA (2 mg/kg) or SB } \\
(200 \mathrm{mg} / \mathrm{kg}) \\
\text { intraperitoneal (i.p.) } \\
\text { injection }\end{array}$ & $\begin{array}{l}\text { Reduced neutrophil infiltration, inhibited } \\
\text { ICAM-1 and E-selectin expression in lung }\end{array}$ & {$[88]$} \\
\hline \multirow{2}{*}{$\begin{array}{l}\text { Ischemia } \\
\text { induced injury }\end{array}$} & \multirow{2}{*}{$\begin{array}{c}\mathrm{SB}(100 \text { or } \\
300 \mathrm{mg} / \mathrm{kg}, \text { i.p. })\end{array}$} & Reduced infarct size & [89] \\
\hline & & $\begin{array}{l}\text { Diminished brain infarct volume and } \\
\text { microglial activation }\end{array}$ & {$[64]$} \\
\hline
\end{tabular}

Abbreviations: Acute lung injury (ALI), Aminosalicylic Acid (ASA), Intercellular Adhesion Molecule (ICAM-1), Interleukin (IL), Nitric oxide (NO), Mieloperoxidase (MPO), Resistant Starch (RS), Short chain fatty acids (SCFA), Trichostatin (TSA), Trinitrobenzenesulfonic acid (TNBS), Tumor Necrosis Factor- $\alpha$ (TNF- $\alpha$ ). 
Sepsis is a condition defined by the presence of both infection and an inflammatory systemic response. In this condition there is an excessive production of inflammatory mediators such as TNF- $\alpha$, IL-1 and high-mobility group box (HMGB1). These mediators cause tissue injury and multiple-organ dysfunction. Despite significant advances in sepsis management, severe sepsis (sepsis with organ dysfunction) and septic shock (a condition characterized by the presence of a hypotension despite adequate volume resuscitation, in the absence of other causes for hypotension) still present mortality rates of 25 to $30 \%$ and 40 to $70 \%$, respectively. Some authors tested whether butyrate could have beneficial effects in this condition [86,87,90]. In a model of sepsis induced by caecal ligation and puncture (CLP) in rats, sodium butyrate administration prevented damage to the liver, kidneys and lungs, and improved the survival rate [86]. The authors associated these effects with a reduction in the production of HMGB1. This mediator is secreted by activated monocytes, macrophages and neutrophils and triggers the release of several pro-inflammatory cytokines (e.g., TNF- $\alpha$ and IL-1) [91] and plays a key role for the establishment of severe sepsis [92].

Promising results were obtained with the use of butyrate for reducing lung injury caused by sepsis [87,93]. Acute lung injury (ALI) is characterized by loss of the alveolar-capillary barrier integrity and refractory hypoxemia [94]. Sepsis is the most usual cause of ALI [95]. The pretreatment with sodium butyrate significantly alleviated septic lung injury and attenuated histological lesions in mice [93]. Reductions of leukocyte infiltration and pulmonary myeloperoxidase (MPO) activity were observed in mice treated with butyrate. Such effects have been associated to inhibition of HDAC activity [93].

In another study in which ALI was induced by intratracheally instillation of LPS in mice, oral administration of butyrate $(10 \mathrm{mg} / \mathrm{kg})$ reduced the concentrations of TNF- $\alpha$, IL- $1 \beta$ and nitric oxide (NO) in bronchoalveolar lavage fluid [87]. Reduction in alveolar hemorrhage and infiltration of neutrophils were also observed indicating a protective effect of butyrate [87].

The effect of sodium butyrate and other inhibitors of HDAC (valproic acid and trichostatin A) was also investigated on tissue injury induced by ischemia [64,89]. Hu et al. found that butyrate pretreatment reduced the infarct size in a model of myocardial ischemia and reperfusion in rats. This beneficial effect of butyrate was attributed to the suppression of HMGB1 production [89]. In rats submitted to cerebral artery occlusion, post-insult treatment with butyrate reduced brain infarct volume and suppressed microglial activation [64]. According to the authors, multiple mechanisms are involved in stroke, and due to the fact that there is no effective treatment for this disease, butyrate should be tested in clinical trials.

\section{Conclusions}

SCFAs present multiple effects in different cells involved in the inflammatory and immune responses. These fatty acids not only affect the function of leukocytes (e.g., production of inflammatory mediators and ability of leukocytes to migrate) but can also induce apoptosis in lymphocytes [96,97], macrophages [98] and neutrophils [99]. The latter effect may be relevant for the outcome of the inflammatory process and the immune response to bacteria that produce these fatty acids.

In general, SCFAs, such as propionate and butyrate, inhibit stimuli-induced expression of adhesion molecules, chemokine production and consequently suppress monocyte/macrophage and neutrophil 
recruitment, suggesting an anti-inflammatory action. However, there is also evidence in favor of a pro-inflammatory action of SCFAs in some conditions [20,100]. This discrepancy may be in part explained by the ability of SCFAs to induce neutrophil migration. In sites of anaerobic bacteria infection or after loss of intestinal epithelial integrity, high concentrations of SCFAs may lead to neutrophil accumulation and amplification of the inflammatory process. Another possible explanation is the fact that these fatty acids may present divergent effects depending on the cell type (e.g., anti- and pro-inflammatory effects of SCFAs on macrophage and microglial cells have been demonstrated [52,97,101]). Therefore, although SCFAs modulate the function of immune cells, more studies are necessary in order to understand the precise role of SCFAs on the interaction between bacteria and host immune cells in vivo, particularly in the GI tract and in sites of anaerobic infections including the skin, oral cavity and respiratory tract.

\section{Acknowledgments}

This work was supported by Fundação de Apoio a Pesquisa do Estado de São Paulo (FAPESP).

\section{References}

1. O'Hara, A.M.; Shanahan, F. The gut flora as a forgotten organ. EMBO Rep. 2006, 7, 688-693.

2. Heijtz, R.D.; Wang, S.; Anuar, F.; Qian, Y.; Bjorkholm, B.; Samuelsson, A.; Hibberd, M.L.; Forssberg, H.; Pettersson, S. Normal gut microbiota modulates brain development and behavior. Proc. Natl. Acad. Sci. USA 2011, 108, 3047-3052.

3. Vijay-Kumar, M.; Aitken, J.D.; Carvalho, F.A.; Cullender, T.C.; Mwangi, S.; Srinivasan, S.; Sitaraman, S.V.; Knight, R.; Ley, R.E.; Gewirtz, A.T. Metabolic syndrome and altered gut microbiota in mice lacking Toll-like receptor 5. Science 2010, 328, 228-231.

4. Maslowski, K.M.; Vieira, A.T.; Ng, A.; Kranich, J.; Sierro, F.; Yu, D.; Schilter, H.C.; Rolph, M.S.; Mackay, F.; Artis, D.; et al. Regulation of inflammatory responses by gut microbiota and chemoattractant receptor GPR43. Nature 2009, 461, 1282-1286.

5. Uronis, J.M.; Muhlbauer, M.; Herfarth, H.H.; Rubinas, T.C.; Jones, G.S.; Jobin, C. Modulation of the intestinal microbiota alters colitis-associated colorectal cancer susceptibility. PLoS One 2009, 4, e6026.

6. De Filippo, C.; Cavalieri, D.; Di Paola, M.; Ramazzotti, M.; Poullet, J.B.; Massart, S.; Collini, S.; Pieraccini, G.; Lionetti, P. Impact of diet in shaping gut microbiota revealed by a comparative study in children from Europe and rural Africa. Proc. Natl. Acad. Sci. USA 2010, 107, 14691-14696.

7. Cani, P.D.; Amar, J.; Iglesias, M.A.; Poggi, M.; Knauf, C.; Bastelica, D.; Neyrinck, A.M.; Fava, F.; Tuohy, K.M.; Chabo, C.; et al. Metabolic endotoxemia initiates obesity and insulin resistance. Diabetes 2007, 56, 1761-1772.

8. Atarashi, K.; Nishimura, J.; Shima, T.; Umesaki, Y.; Yamamoto, M.; Onoue, M.; Yagita, H.; Ishii, N.; Evans, R.; Honda, K.; et al. ATP drives lamina propria $\mathrm{T}(\mathrm{H}) 17$ cell differentiation. Nature 2008, 455, 808-812. 
9. Huda-Faujan, N.; Abdulamir, A.S.; Fatimah, A.B.; Anas, O.M.; Shuhaimi, M.; Yazid, A.M.; Loong, Y.Y. The impact of the level of the intestinal short chain Fatty acids in inflammatory bowel disease patients versus healthy subjects. Open Biochem. J. 2010, 4, 53-58.

10. Vernia, P.; Caprilli, R.; Latella, G.; Barbetti, F.; Magliocca, F.M.; Cittadini, M. Fecal lactate and ulcerative colitis. Gastroenterology 1988, 95, 1564-1568.

11. Murphy, E.F.; Cotter, P.D.; Healy, S.; Marques, T.M.; O’Sullivan, O.; Fouhy, F.; Clarke, S.F.; O'Toole, P.W.; Quigley, E.M.; Stanton, C.; et al. Composition and energy harvesting capacity of the gut microbiota: relationship to diet, obesity and time in mouse models. Gut 2010, 59, 1635-1642.

12. McIntyre, A.; Gibson, P.R.; Young, G.P. Butyrate production from dietary fibre and protection against large bowel cancer in a rat model. Gut 1993, 34, 386-391.

13. Schwiertz, A.; Taras, D.; Schafer, K.; Beijer, S.; Bos, N.A.; Donus, C.; Hardt, P.D. Microbiota and SCFA in lean and overweight healthy subjects. Obesity 2010, 18, 190-195.

14. Cummings, J.H.; Pomare, E.W.; Branch, W.J.; Naylor, C.P.; Macfarlane, G.T. Short chain fatty acids in human large intestine, portal, hepatic and venous blood. Gut 1987, 28, 1221-1227.

15. McNeil, N.I. The contribution of the large intestine to energy supplies in man. Am. J. Clin. Nutr. 1984, 39, 338-342.

16. Zaibi, M.S.; Stocker, C.J.; O’Dowd, J.; Davies, A.; Bellahcene, M.; Cawthorne, M.A.; Brown, A.J.; Smith, D.M.; Arch, J.R. Roles of GPR41 and GPR43 in leptin secretory responses of murine adipocytes to short chain fatty acids. FEBS Lett. 2010, 584, 2381-2386.

17. Plaisancie, P.; Dumoulin, V.; Chayvialle, J.A.; Cuber, J.C. Luminal peptide YY-releasing factors in the isolated vascularly perfused rat colon. J. Endocrinol. 1996, 151, 421-429.

18. Vinolo, M.A.; Rodrigues, H.G.; Hatanaka, E.; Sato, F.T.; Sampaio, S.C.; Curi, R. Suppressive effect of short-chain fatty acids on production of proinflammatory mediators by neutrophils. J. Nutr. Biochem. 2011, 22, 849-855.

19. Luster, A.D.; Alon, R.; von Andrian, U.H. Immune cell migration in inflammation: present and future therapeutic targets. Nat. Immunol. 2005, 6, 1182-1190.

20. Vinolo, M.A.; Rodrigues, H.G.; Hatanaka, E.; Hebeda, C.B.; Farsky, S.H.; Curi, R. Short-chain fatty acids stimulate the migration of neutrophils to inflammatory sites. Clin. Sci. 2009, 117, 331-338.

21. Vinolo, M.A.; Rodrigues, H.G.; Hatanaka, E.; Sato, F.T.; Sampaio, S.C.; Curi, R. Suppressive effect of short chain fatty acids on production of proinflammatory mediators by neutrophils. J. Nutr. Biochem. 2011, 22, 849-855.

22. Le Poul, E.; Loison, C.; Struyf, S.; Springael, J.Y.; Lannoy, V.; Decobecq, M.E.; Brezillon, S.; Dupriez, V.; Vassart, G.; Van Damme, J.; et al. Functional characterization of human receptors for short chain fatty acids and their role in polymorphonuclear cell activation. J. Biol. Chem. 2003, 278, 25481-25489.

23. Park, J.S.; Lee, E.J.; Lee, J.C.; Kim, W.K.; Kim, H.S. Anti-inflammatory effects of short chain fatty acids in IFN-gamma-stimulated RAW 264.7 murine macrophage cells: Involvement of NF-kappaB and ERK signaling pathways. Int. Immunopharmacol. 2007, 7, 70-77. 
24. Sina, C.; Gavrilova, O.; Forster, M.; Till, A.; Derer, S.; Hildebrand, F.; Raabe, B.; Chalaris, A.; Scheller, J.; Rehmann, A.; et al. G protein-coupled receptor 43 is essential for neutrophil recruitment during intestinal inflammation. J. Immunol. 2009, 183, 7514-7522.

25. Vinolo, M.A.; Ferguson, G.J.; Kulkarni, S.; Damoulakis, G.; Anderson, K.; Bohlooly, Y.M.; Stephens, L.; Hawkins, P.T.; Curi, R. SCFAs Induce Mouse Neutrophil Chemotaxis through the GPR43 Receptor. PLoS One 2011, 6, e21205.

26. Brown, A.J.; Goldsworthy, S.M.; Barnes, A.A.; Eilert, M.M.; Tcheang, L.; Daniels, D.; Muir, A.I.; Wigglesworth, M.J.; Kinghorn, I.; Fraser, N.J.; et al. The Orphan G protein-coupled receptors GPR41 and GPR43 are activated by propionate and other short chain carboxylic acids. J. Biol. Chem. 2003, 278, 11312-11319.

27. Nilsson, N.E.; Kotarsky, K.; Owman, C.; Olde, B. Identification of a free fatty acid receptor, FFA2R, expressed on leukocytes and activated by short-chain fatty acids. Biochem. Biophys. Res. Commun. 2003, 303, 1047-1052.

28. Itoh, Y.; Kawamata, Y.; Harada, M.; Kobayashi, M.; Fujii, R.; Fukusumi, S.; Ogi, K.; Hosoya, M.; Tanaka, Y.; Uejima, H.; et al. Free fatty acids regulate insulin secretion from pancreatic beta cells through GPR40. Nature 2003, 422, 173-176.

29. Maa, M.C.; Chang, M.Y.; Hsieh, M.Y.; Chen, Y.J.; Yang, C.J.; Chen, Z.C.; Li, Y.K.; Yen, C.K.; Wu, R.R.; Leu, T.H. Butyrate reduced lipopolysaccharide-mediated macrophage migration by suppression of Src enhancement and focal adhesion kinase activity. J. Nutr. Biochem. 2010, 21, $1186-1192$.

30. Owen, K.A.; Pixley, F.J.; Thomas, K.S.; Vicente-Manzanares, M.; Ray, B.J.; Horwitz, A.F.; Parsons, J.T.; Beggs, H.E.; Stanley, E.R.; Bouton, A.H. Regulation of lamellipodial persistence, adhesion turnover, and motility in macrophages by focal adhesion kinase. J. Cell Biol. 2007, 179, $1275-1287$.

31. Zapolska-Downar, D.; Naruszewicz, M. Propionate reduces the cytokine-induced VCAM-1 and ICAM-1 expression by inhibiting nuclear factor-kappa B (NF-kappaB) activation. J. Physiol. Pharmacol. 2009, 60, 123-131.

32. Zapolska-Downar, D.; Siennicka, A.; Kaczmarczyk, M.; Kolodziej, B.; Naruszewicz, M. Butyrate inhibits cytokine-induced VCAM-1 and ICAM-1 expression in cultured endothelial cells: The role of NF-kappaB and PPARalpha. J. Nutr. Biochem. 2004, 15, 220-228.

33. Miller, S.J.; Zaloga, G.P.; Hoggatt, A.M.; Labarrere, C.; Faulk, W.P. Short-chain fatty acids modulate gene expression for vascular endothelial cell adhesion molecules. Nutrition 2005, 21, $740-748$.

34. Cox, M.A.; Jackson, J.; Stanton, M.; Rojas-Triana, A.; Bober, L.; Laverty, M.; Yang, X.; Zhu, F.; Liu, J.; Wang, S.; et al. Short-chain fatty acids act as antiinflammatory mediators by regulating prostaglandin E(2) and cytokines. World J. Gastroenterol. 2009, 15, 5549-5557.

35. Blais, M.; Seidman, E.G.; Asselin, C. Dual effect of butyrate on IL-1beta-mediated intestinal epithelial cell inflammatory response. DNA Cell Biol. 2007, 26, 133-147.

36. Leung, C.H.; Lam, W.; Ma, D.L.; Gullen, E.A.; Cheng, Y.C. Butyrate mediates nucleotide-binding and oligomerisation domain (NOD) 2-dependent mucosal immune responses against peptidoglycan. Eur. J. Immunol. 2009, 39, 3529-3537. 
37. Bocker, U.; Nebe, T.; Herweck, F.; Holt, L.; Panja, A.; Jobin, C.; Rossol, S.; Sartor, R.B.; Singer, M.V. Butyrate modulates intestinal epithelial cell-mediated neutrophil migration. Clin. Exp. Immunol. 2003, 131, 53-60.

38. Fusunyan, R.D.; Quinn, J.J.; Fujimoto, M.; MacDermott, R.P.; Sanderson, I.R. Butyrate switches the pattern of chemokine secretion by intestinal epithelial cells through histone acetylation. Mol. Med. 1999, 5, 631-640.

39. Inatomi, O.; Andoh, A.; Kitamura, K.; Yasui, H.; Zhang, Z.; Fujiyama, Y. Butyrate blocks interferon-gamma-inducible protein-10 release in human intestinal subepithelial myofibroblasts. J. Gastroenterol. 2005, 40, 483-489.

40. Menzel, T.; Luhrs, H.; Zirlik, S.; Schauber, J.; Kudlich, T.; Gerke, T.; Gostner, A.; Neumann, M.; Melcher, R.; Scheppach, W. Butyrate inhibits leukocyte adhesion to endothelial cells via modulation of VCAM-1. Inflamm. Bowel Dis. 2004, 10, 122-128.

41. Bohmig, G.A.; Krieger, P.M.; Saemann, M.D.; Wenhardt, C.; Pohanka, E.; Zlabinger, G.J. $n$-Butyrate downregulates the stimulatory function of peripheral blood-derived antigen-presenting cells: A potential mechanism for modulating T-cell responses by short-chain fatty acids. Immunology 1997, 92, 234-243.

42. Dianzani, C.; Cavalli, R.; Zara, G.P.; Gallicchio, M.; Lombardi, G.; Gasco, M.R.; Panzanelli, P.; Fantozzi, R. Cholesteryl butyrate solid lipid nanoparticles inhibit adhesion of human neutrophils to endothelial cells. Br. J. Pharmacol. 2006, 148, 648-656.

43. Allport, J.R.; Ding, H.T.; Ager, A.; Steeber, D.A.; Tedder, T.F.; Luscinskas, F.W. L-selectin shedding does not regulate human neutrophil attachment, rolling, or transmigration across human vascular endothelium in vitro. J. Immunol. 1997, 158, 4365-4372.

44. Olefsky, J.M.; Glass, C.K. Macrophages, inflammation, and insulin resistance. Annu. Rev. Physiol. 2010, 72, 219-246.

45. Kinne, R.W.; Brauer, R.; Stuhlmuller, B.; Palombo-Kinne, E.; Burmester, G.R. Macrophages in rheumatoid arthritis. Arthritis Res. 2000, 2, 189-202.

46. Griffin, W.S. Inflammation and neurodegenerative diseases. Am. J. Clin. Nutr. 2006, 83, 470S-474S.

47. Boyle, J.J. Macrophage activation in atherosclerosis: Pathogenesis and pharmacology of plaque rupture. Curr. Vasc. Pharmacol. 2005, 3, 63-68.

48. Chakravortty, D.; Koide, N.; Kato, Y.; Sugiyama, T.; Mu, M.M.; Yoshida, T.; Yokochi, T. The inhibitory action of butyrate on lipopolysaccharide-induced nitric oxide production in RAW 264.7 murine macrophage cells. J. Endotoxin Res. 2000, 6, 243-247.

49. Usami, M.; Kishimoto, K.; Ohata, A.; Miyoshi, M.; Aoyama, M.; Fueda, Y.; Kotani, J. Butyrate and trichostatin $\mathrm{A}$ attenuate nuclear factor kappaB activation and tumor necrosis factor alpha secretion and increase prostaglandin E2 secretion in human peripheral blood mononuclear cells. Nutr. Res. 2008, 28, 321-328.

50. Fukae, J.; Amasaki, Y.; Yamashita, Y.; Bohgaki, T.; Yasuda, S.; Jodo, S.; Atsumi, T.; Koike, T. Butyrate suppresses tumor necrosis factor alpha production by regulating specific messenger RNA degradation mediated through a cis-acting AU-rich element. Arthritis Rheum. 2005, 52, 2697-2707. 
51. Saemann, M.D.; Bohmig, G.A.; Osterreicher, C.H.; Burtscher, H.; Parolini, O.; Diakos, C.; Stockl, J.; Horl, W.H.; Zlabinger, G.J. Anti-inflammatory effects of sodium butyrate on human monocytes: Potent inhibition of IL-12 and up-regulation of IL-10 production. FASEB J. 2000, 14, 2380-2382.

52. Huuskonen, J.; Suuronen, T.; Nuutinen, T.; Kyrylenko, S.; Salminen, A. Regulation of microglial inflammatory response by sodium butyrate and short-chain fatty acids. Br. J. Pharmacol. 2004, $141,874-880$.

53. Park, J.S.; Woo, M.S.; Kim, S.Y.; Kim, W.K.; Kim, H.S. Repression of interferon-gamma-induced inducible nitric oxide synthase (iNOS) gene expression in microglia by sodium butyrate is mediated through specific inhibition of ERK signaling pathways. J. Neuroimmunol. 2005, 168, 56-64.

54. Chen, P.S.; Wang, C.C.; Bortner, C.D.; Peng, G.S.; Wu, X.; Pang, H.; Lu, R.B.; Gean, P.W.; Chuang, D.M.; Hong, J.S. Valproic acid and other histone deacetylase inhibitors induce microglial apoptosis and attenuate lipopolysaccharide-induced dopaminergic neurotoxicity. Neuroscience 2007, 149, 203-212.

55. Perez, R.; Stevenson, F.; Johnson, J.; Morgan, M.; Erickson, K.; Hubbard, N.E.; Morand, L.; Rudich, S.; Katznelson, S.; German, J.B. Sodium butyrate upregulates Kupffer cell PGE2 production and modulates immune function. J. Surg. Res. 1998, 78, 1-6.

56. Waldecker, M.; Kautenburger, T.; Daumann, H.; Busch, C.; Schrenk, D. Inhibition of histone-deacetylase activity by short-chain fatty acids and some polyphenol metabolites formed in the colon. J. Nutr. Biochem. 2008, 19, 587-593.

57. Glozak, M.A.; Sengupta, N.; Zhang, X.; Seto, E. Acetylation and deacetylation of non-histone proteins. Gene 2005, 363, 15-23.

58. Cox, H.M.; Tough, I.R.; Woolston, A.M.; Zhang, L.; Nguyen, A.D.; Sainsbury, A.; Herzog, H. Peptide YY is critical for acylethanolamine receptor Gpr119-induced activation of gastrointestinal mucosal responses. Cell Metab. 2010, 11, 532-542.

59. Yao, C.; Sakata, D.; Esaki, Y.; Li, Y.; Matsuoka, T.; Kuroiwa, K.; Sugimoto, Y.; Narumiya, S. Prostaglandin E2-EP4 signaling promotes immune inflammation through Th1 cell differentiation and Th17 cell expansion. Nat. Med. 2009, 15, 633-640.

60. Sakata, D.; Yao, C.; Narumiya, S. Prostaglandin E2, an immunoactivator. J. Pharmacol. Sci. 2010, 112, 1-5.

61. Serhan, C.N.; Krishnamoorthy, S.; Recchiuti, A.; Chiang, N. Novel anti-inflammatorypro-resolving mediators and their receptors. Curr. Top. Med. Chem. 2011, 11, 629-647.

62. Tedelind, S.; Westberg, F.; Kjerrulf, M.; Vidal, A. Anti-inflammatory properties of the short-chain fatty acids acetate and propionate: A study with relevance to inflammatory bowel disease. World J. Gastroenterol. 2007, 13, 2826-2832.

63. Nakamura, Y. Regulating factors for microglial activation. Biol. Pharm. Bull. 2002, 25, 945-953.

64. Kim, H.J.; Rowe, M.; Ren, M.; Hong, J.S.; Chen, P.S.; Chuang, D.M. Histone deacetylase inhibitors exhibit anti-inflammatory and neuroprotective effects in a rat permanent ischemic model of stroke: Multiple mechanisms of action. J. Pharmacol. Exp. Ther. 2007, 321, 892-901.

65. Vinolo, M.A.; Hatanaka, E.; Lambertucci, R.H.; Newsholme, P.; Curi, R. Effects of short chain fatty acids on effector mechanisms of neutrophils. Cell Biochem. Funct. 2009, 27, 48-55. 
66. Mills, S.W.; Montgomery, S.H.; Morck, D.W. Evaluation of the effects of short-chain fatty acids and extracellular pH on bovine neutrophil function in vitro. Am. J. Vet. Res. 2006, 67, 1901-1907.

67. Eftimiadi, C.; Buzzi, E.; Tonetti, M.; Buffa, P.; Buffa, D.; van Steenbergen, M.T.; de Graaff, J.; Botta, G.A. Short-chain fatty acids produced by anaerobic bacteria alter the physiological responses of human neutrophils to chemotactic peptide. J. Infect. 1987, 14, 43-53.

68. Eftimiadi, C.; Tonetti, M.; Cavallero, A.; Sacco, O.; Rossi, G.A. Short-chain fatty acids produced by anaerobic bacteria inhibit phagocytosis by human lung phagocytes. J. Infect. Dis. 1990, 161, $138-142$.

69. Millard, A.L.; Mertes, P.M.; Ittelet, D.; Villard, F.; Jeannesson, P.; Bernard, J. Butyrate affects differentiation, maturation and function of human monocyte-derived dendritic cells and macrophages. Clin. Exp. Immunol. 2002, 130, 245-255.

70. Stringer, R.E.; Hart, C.A.; Edwards, S.W. Sodium butyrate delays neutrophil apoptosis: Role of protein biosynthesis in neutrophil survival. Br. J. Haematol. 1996, 92, 169-175.

71. Nakao, S.; Moriya, Y.; Furuyama, S.; Niederman, R.; Sugiya, H. Propionic acid stimulates superoxide generation in human neutrophils. Cell Biol. Int. 1998, 22, 331-337.

72. Tonetti, M.; Cavallero, A.; Botta, G.A.; Niederman, R.; Eftimiadi, C. Intracellular pH regulates the production of different oxygen metabolites in neutrophils: Effects of organic acids produced by anaerobic bacteria. J. Leukoc. Biol. 1991, 49, 180-188.

73. Liu, Q.; Shimoyama, T.; Suzuki, K.; Umeda, T.; Nakaji, S.; Sugawara, K. Effect of sodium butyrate on reactive oxygen species generation by human neutrophils. Scand. J. Gastroenterol. 2001, 36, 744-750.

74. Sandoval, A.; Trivinos, F.; Sanhueza, A.; Carretta, D.; Hidalgo, M.A.; Hancke, J.L.; Burgos, R.A. Propionate induces $\mathrm{pH}(\mathrm{i})$ changes through calcium flux, ERK1/2, p38, and PKC in bovine neutrophils. Vet. Immunol. Immunopathol. 2007, 115, 286-298.

75. Cavaglieri, C.R.; Nishiyama, A.; Fernandes, L.C.; Curi, R.; Miles, E.A.; Calder, P.C. Differential effects of short-chain fatty acids on proliferation and production of pro- and anti-inflammatory cytokines by cultured lymphocytes. Life Sci. 2003, 73, 1683-1690.

76. Dagtas, A.S.; Edens, R.E.; Gilbert, K.M. Histone deacetylase inhibitor uses p21(Cip1) to maintain anergy in CD4+ T cells. Int. Immunopharmacol. 2009, 9, 1289-1297.

77. Tao, R.; de Zoeten, E.F.; Ozkaynak, E.; Chen, C.; Wang, L.; Porrett, P.M.; Li, B.; Turka, L.A.; Olson, E.N.; Greene, M.I.; Wells, A.D.; Hancock, W.W. Deacetylase inhibition promotes the generation and function of regulatory T cells. Nat. Med. 2007, 13, 1299-1307.

78. Jacobasch, G.; Schmiedl, D.; Kruschewski, M.; Schmehl, K. Dietary resistant starch and chronic inflammatory bowel diseases. Int. J. Colorectal Dis. 1999, 14, 201-211.

79. Nishimura, T.; Andoh, A.; Hashimoto, T.; Kobori, A.; Tsujikawa, T.; Fujiyama, Y. Cellobiose prevents the development of dextran sulfate sodium (DSS)-induced experimental colitis. J. Clin. Biochem. Nutr. 2010, 46, 105-110.

80. Rodriguez-Cabezas, M.E.; Galvez, J.; Lorente, M.D.; Concha, A.; Camuesco, D.; Azzouz, S.; Osuna, A.; Redondo, L.; Zarzuelo, A. Dietary fiber down-regulates colonic tumor necrosis factor alpha and nitric oxide production in trinitrobenzenesulfonic acid-induced colitic rats. J. Nutr. 2002, 132, 3263-3271. 
81. Tarrerias, A.L.; Millecamps, M.; Alloui, A.; Beaughard, C.; Kemeny, J.L.; Bourdu, S.; Bommelaer, G.; Eschalier, A.; Dapoigny, M.; Ardid, D. Short-chain fatty acid enemas fail to decrease colonic hypersensitivity and inflammation in TNBS-induced colonic inflammation in rats. Pain 2002, 100, 91-97.

82. Scheppach, W.; Sommer, H.; Kirchner, T.; Paganelli, G.M.; Bartram, P.; Christl, S.; Richter, F.; Dusel, G.; Kasper, H. Effect of butyrate enemas on the colonic mucosa in distal ulcerative colitis. Gastroenterology 1992, 103, 51-56.

83. Hamer, H.M.; Jonkers, D.M.; Vanhoutvin, S.A.; Troost, F.J.; Rijkers, G.; de Bruine, A.; Bast, A.; Venema, K.; Brummer, R.J. Effect of butyrate enemas on inflammation and antioxidant status in the colonic mucosa of patients with ulcerative colitis in remission. Clin. Nutr. 2010, 29, 738-744.

84. Vernia, P.; Annese, V.; Bresci, G.; d'Albasio, G.; D’Inca, R.; Giaccari, S.; Ingrosso, M.; Mansi, C.; Riegler, G.; Valpiani, D.; et al. Topical butyrate improves efficacy of 5-ASA in refractory distal ulcerative colitis: results of a multicentre trial. Eur. J. Clin. Invest. 2003, 33, 244-248.

85. Vieira, E.L.; Leonel, A.J.; Sad, A.P.; Beltrao, N.R.; Costa, T.F.; Ferreira, T.M.; Gomes-Santos, A.C.; Faria, A.M.; Peluzio, M.C.; Cara, D.C.; et al. Oral administration of sodium butyrate attenuates inflammation and mucosal lesion in experimental acute ulcerative colitis. J. Nutr. Biochem. 2011, doi:10.1016/j.jnutbio.2011.01.007.

86. Zhang, L.T.; Yao, Y.M.; Lu, J.Q.; Yan, X.J.; Yu, Y.; Sheng, Z.Y. Sodium butyrate prevents lethality of severe sepsis in rats. Shock 2007, 27, 672-677.

87. Ni, Y.F.; Wang, J.; Yan, X.L.; Tian, F.; Zhao, J.B.; Wang, Y.J.; Jiang, T. Histone deacetylase inhibitor, butyrate, attenuates lipopolysaccharide-induced acute lung injury in mice. Respir. Res. 2010, 11, 33 .

88. Zhang, L.; Jin, S.; Wang, C.; Jiang, R.; Wan, J. Histone deacetylase inhibitors attenuate acute lung injury during cecal ligation and puncture-induced polymicrobial sepsis. World J. Surg. 2010, 34, 1676-1683.

89. Hu, X.; Xu, C.; Zhou, X.; He, B.; Wu, L.; Cui, B.; Lu, Z.; Jiang, H. Sodium butyrate protects against myocardial ischemia and reperfusion injury by inhibiting high mobility group box 1 protein in rats. Biomed. Pharmacother. 2010, doi:10.1016/j.biopha.2010.09.005.

90. Weber, T.E.; Kerr, B.J. Effect of sodium butyrate on growth performance and response to lipopolysaccharide in weanling pigs. J. Anim. Sci. 2008, 86, 442-450.

91. Wang, H.; Bloom, O.; Zhang, M.; Vishnubhakat, J.M.; Ombrellino, M.; Che, J.; Frazier, A.; Yang, H.; Ivanova, S.; Borovikova, L.; et al. HMG-1 as a late mediator of endotoxin lethality in mice. Science 1999, 285, 248-251.

92. Ulloa, L.; Tracey, K.J. The "cytokine profile": A code for sepsis. Trends Mol. Med. 2005, 11, $56-63$.

93. Zhang, L.; Jin, S.; Wang, C.; Jiang, R.; Wan, J. Histone deacetylase inhibitors attenuate acute lung injury during cecal ligation and puncture-induced polymicrobial sepsis. World J. Surg. 2010, 34, 1676-1683.

94. Ware, L.B.; Matthay, M.A. The acute respiratory distress syndrome. N. Engl. J. Med. 2000, 342, 1334-1349. 
95. Balibrea, J.L.; Arias-Diaz, J. Acute respiratory distress syndrome in the septic surgical patient. World J. Surg. 2003, 27, 1275-1284.

96. Kurita-Ochiai, T.; Ochiai, K.; Fukushima, K. Butyric acid-induced T-cell apoptosis is mediated by caspase-8 and -9 activation in a Fas-independent manner. Clin. Diagn. Lab. Immunol. 2001, 8, 325-332.

97. Bailon, E.; Cueto-Sola, M.; Utrilla, P.; Rodriguez-Cabezas, M.E.; Garrido-Mesa, N.; Zarzuelo, A.; Xaus, J.; Galvez, J.; Comalada, M. Butyrate in vitro immune-modulatory effects might be mediated through a proliferation-related induction of apoptosis. Immunobiology 2010, 215, 863-873.

98. Ramos, M.G.; Rabelo, F.L.; Duarte, T.; Gazzinelli, R.T.; Alvarez-Leite, J.I. Butyrate induces apoptosis in murine macrophages via caspase-3, but independent of autocrine synthesis of tumor necrosis factor and nitric oxide. Braz. J. Med. Biol. Res. 2002, 35, 161-173.

99. Aoyama, M.; Kotani, J.; Usami, M. Butyrate and propionate induced activated or non-activated neutrophil apoptosis via HDAC inhibitor activity but without activating GPR-41/GPR-43 pathways. Nutrition 2010, 26, 653-661.

100. Niederman, R.; Buyle-Bodin, Y.; Lu, B.Y.; Robinson, P.; Naleway, C. Short-chain carboxylic acid concentration in human gingival crevicular fluid. J. Dent. Res. 1997, 76, 575-579.

101. Halili, M.A.; Andrews, M.R.; Labzin, L.I.; Schroder, K.; Matthias, G.; Cao, C.; Lovelace, E.; Reid, R.C.; Le, G.T.; Hume, D.A.; et al. Differential effects of selective HDAC inhibitors on macrophage inflammatory responses to the Toll-like receptor 4 agonist LPS. J. Leukoc. Biol. 2010, $87,1103-1114$.

(C) 2011 by the authors; licensee MDPI, Basel, Switzerland. This article is an open access article distributed under the terms and conditions of the Creative Commons Attribution license (http://creativecommons.org/licenses/by/3.0/). 